PAEDAGOGIA ChRISTIANA

I/21 (2008) - ISSN 1505-6872

Barbara Drażkowska*

Toruń

\title{
Kościół w świecie mediów. Ewangelizacja w dobie komputerów
}

Idźcie więc i nauczajcie wszystkie narody (Mt 28, 19a).

Kościół XXI wieku, pragnąc realizować misję ewangelizacji powierzoną mu przez Chrystusa, nie pozostaje obojętny na dobro, jakie niosą za sobą środki społecznego przekazu, wyznaczające kierunek i poziom współczesnej kultury i cywilizacji ${ }^{1}$. Mass media wchodzą obecnie w skład podstawowego środowiska życia i wzrastania człowieka. Dlatego również w tym środowisku ludzie powinni usłyszeć i poznać Dobrą Nowinę, a także dowiedzieć się, w jaki sposób uczynić ją treścią swego życia i zanieść innym, w miarę swych możliwości².

Wyrażenie środki społecznego przekazu oznacza współczesne techniki komunikacji. W obszarze języków anglosaskich używa się głównie terminu mass media, natomiast w krajach Ameryki Łacińskiej Comunicacion colectiva ${ }^{3}$. Termin mass media znajduje swe korzenie w końcu XIX i na początku XX wieku, gdy szybki rozwój przemysłu i nowych technologii (głównie w USA) spowodował, że określone dobra kultury, takie jak: gazety, filmy, radio, telewizory, były produkowane masowo, dla wielu odbiorców. Stąd na określenie zaistniałego zjawiska zaczęto używać neologizmu mass media ${ }^{4}$.

Środki społecznego przekazu kształtują i determinują prawie każde zdarzenie obecne w naszej kulturze, kształtują nasz sposób widzenia świata. W coraz

* Dr Barbara Drążkowska, pracownik Papieskiego Wydziału Teologicznego, Sekcji Św. Jana Chrzciciela, Studium Teologii we Włocławku; Toruńskiej Szkoły Terapeutycznej; Szkoły Społecznej Stowarzyszenia „Edukacja”.

${ }^{1}$ Por. S. Pamuła, Środki społecznego przekazu a dzieło ewangelizacji, HD 61 (1993) nr 1, s. 22.

${ }^{2}$ Por. tamże.

${ }^{3}$ Por. tamże.

${ }^{4}$ Por. tamże. 
większym zakresie używamy tych środków, poszerzających możliwości ludzkiego działania do tego stopnia, że mogą powodować istotne zmiany ${ }^{5}$. Kultura jest właśnie rezultatem takiego zmieniania się, przerastania i stawania się. Człowiek może dojść do pełni człowieczeństwa tylko poprzez nią, a to oznacza pielęgnowanie naturalnych dóbr i wartości ${ }^{6}$. Kultury zmieniają się pod wpływem ludzkich postaw. W ten sposób ludzka duchowość staje się jednocześnie twórcą i wytworem własnej kultury ${ }^{7}$, a świat, w którym obecnie żyjemy i cywilizacyjne przemiany znajdują swój wyraz właśnie w środkach przekazu, które starają się zaspokoić każdy gust ${ }^{8}$.

Przyjrzyjmy się jednak bliżej samemu zagadnieniu obecności Kościoła w mediach, czy mediów w służbie Kościoła. Jak bowiem czytamy w Lumen Gentium: „normalny rytm i pełnienie zadań w Kościele wymagaja, by pomiędzy władzami kościelnymi na wszystkich poziomach, instytucjami kościelnymi a wiernymi miał miejsce ciągły przepływ wiadomości i opinii” (KO, $\mathrm{nr} 1)$.

\section{Relacje Kościoła i świata mediów}

Wartości duchowe, które są głoszone przez Kościół, wymagają, by podawanie informacji o jego poczynaniach i zamiarach było dokonane $\mathrm{z}$ maksymalną otwartością i odpowiedzialnością za prawdę. W gąszczu informacyjnym, z jakim bez wątpienia mamy obecnie do czynienia, media powinny zatem przyjąć taką strukturę, by nauczyć chrześcijan oraz poszukujących dopiero Kościoła, w jaki sposób poradzić sobie z tym ogromnym bogactwem informacji, jak sprawić, by wartości ewangeliczne wypełniły wszystkie obszary życia społecznego. Aby mogło to nastąpić w społeczeństwie i kulturze zdominowanej przez mass media, chrześcijanie powinni wyodrębnić w przekazie medialnym to, co jest wyrazem wartości prawdziwie chrześcijańskich ${ }^{9}$. Dostęp do światowych zasobów informacyjnych i możliwość praktycznie nieograniczonego komunikowania się są nieocenionym darem dla ludzkości. Manipulacje i przestępstwa, z którymi spotykamy się w tej dziedzinie, nie przekreślają jej wartości, zależą bowiem od człowieka, który stoi za każdym czynem, dobrym czy złym ${ }^{10}$. Dlatego tylko od niego zależy, czy wykorzysta mass media przeciw drugiemu człowiekowi, czy zastosuje je w „dobrej sprawie”, jaką bez wattpienia jest realizacja nakazu Chrystusa, dotyczącego dzieła ewangelizacji świata. Środki masowego przekazu

${ }^{5}$ Por. tamże.

${ }^{6}$ Por. B. Bagdikian, The Media Monopoly, Boston 1983, s. 192.

${ }^{7}$ Por. A. Huter, Zur Ausbreitung von Vergnügung und Belehrung... Fernsehen als Kulturwirklichkeit, Zurich 1988, s. 42.

${ }^{8}$ Por. T. Zasępa, Media, człowiek, społeczeństwo. Doświadczenia europejsko-amerykańskie, Częstochowa 2000, s. 68-70.

${ }^{9}$ Por. tamże, s. 279.

${ }^{10}$ Tamże, s. 280. 
bowiem (a szczególnie filmy) wpływają w dużym stopniu na transcendentne doznania w życiu codziennym. Neil Hurley twierdzi nawet, że film jest dla człowieka tym, czym teologia dla elity ${ }^{11}$, a Sallie TeSelle wspomina o wprowadzeniu w życie „teologicznej wyobraźni”"12. Mircea Eliade twierdzi natomiast, że prawdziwa transcendentna chwila pojawia się dzięki naturalnym, znanym elementom świeckiego życia ${ }^{13}$. Główne źródło potęgi mass mediów tkwi zatem w ich zdolności do zaangażowania wyobraźni. Sprawia to, że jakiekolwiek próby zrozumienia i oceny środków masowego przekazu w moralnym rozwoju współczesnej kultury powinny brać pod uwagę związek mediów z ludzką wyobraźnią, która jest czymś więcej niż bierną zdolnością odbierania obrazów stworzonych przez kogoś innego. Wyobraźnia jest bowiem zdolnością aktywną. Dlatego właśnie media przykuwają ludzką wyobraźnię w sposób moralnie ważny, prezentując możliwości powiększania lub pomniejszania stopnia identyfikacji z innymi ludźmi ${ }^{14}$.

Od czasu, gdy wynaleziony został druk, media umożliwiły ogromnej części ludzkości uczestniczenie w „wizjach” innych ludzi, a nawet stworzyły możliwość przekazania własnych wizji coraz szybciej i coraz dalej. Od prasy drukarskiej przeszliśmy bowiem do kserokopiarek, telefaksów, telekonferencji, magnetofonów, magnetowidów, kamer wideo i sieci komputerowych ${ }^{15}$. Wyobraźnia człowieka „popychała” możliwości komunikacji, a co za tym idzie i możliwości mediów coraz dalej i dalej. Staliśmy się świadkami obecności tak zwanej czwartej władzy i tylko od nas zależy, w jaki sposób spożytkujemy jej potęgę. Na tym tle Kościół, zaangażowany w misję ewangelizacji świata, nie może rezygnować z żadnego z mediów, aby dotrzeć z Dobrą Nowiną do odbiorców, ale powinien koncentrować się na poznawaniu ich właściwości i możliwości.

Badania nad mediami, nad sposobem masowego komunikowania się, prowadzone są w ramach rozlicznych dyscyplin naukowych, między innymi socjologii, psychologii, politologii czy dziedziny zwanej Mass Communication Research. Od kilkudziesięciu lat również Kościół zajmuje się tą problematyką. Powstała nawet teologia mass mediów ${ }^{16}$, badająca omawiane zjawiska w kontekście nauki i doktryny katolickiej ${ }^{17}$. Sięga ona do źródeł i prezentuje stanowisko Magisterium we wspomnianym zakresie.

Sobór Watykański II podjął na przykład sprawę mass mediów w Dekrecie o środkach społecznego przekazu myśli Inter mirifica z 1963 roku. Dekret ten w pierwszej części prezentował doktrynę Kościoła na omawiany temat, a w dru-

${ }^{11}$ Szerzej patrz: N. Hurley, Theology Through Film, New York 1970.

${ }^{12}$ Por. S. TeSelle, Speaking in Parables, Philadelphia 1975, s. 8.

${ }^{13}$ Por. M. Eliade, Dreams and Mysteries, New York 1961, s. 11.

${ }^{14}$ Por. T. Zasępa, dz. cyt., s. 299.

${ }^{15}$ Por. tamże, s. 307.

${ }^{16}$ Patrz: E. Baragli, W kierunku teologii środków społecznego przekazu, Teologia w Polsce 19 (1987), s. 4-16; R. Rynkowski, Teologia w sieci, Więź 10 (1999), s. 179-183.

${ }^{17}$ Por. K. Pokorna-Ignatowicz, Kościół w świecie mediów. Historia - dokumenty - dylematy, Kraków 2002, s. 10. 
giej przedstawiał działalność Kościoła w tym obszarze. Stanowił on pierwszy dokument Kościoła ukazujący wszystkie media w sposób komplementarny. Jego największym osiągnięciem było polecenie wprowadzenia Światowego Dnia Środków Społecznego Przekazu ${ }^{18}$. Omawiany dekret należy jednak rozpatrywać w ścisłym związku z instrukcją wykonawczą do niego wydaną w 1971 roku, Instrukcją Papieskiej Komisji do Spraw Środków Społecznego Przekazu ${ }^{19}$, zatytułowaną Communio et progressio. W dwudziestą rocznicę ogłoszenia tej instrukcji Papieska Komisja do Spraw Środków Społecznego Przekazu ogłosiła kolejną instrukcję duszpasterską o przekazie społecznym Aetatis novae ${ }^{20}$.

Kościół postrzega obecnie środki masowego przekazu jako określone dobro, leżące na linii wyznaczonej przez Boga w Jego zamiarach, planach w stosunku do człowieka ${ }^{21}$. Jednak stosunek Kościoła do mass mediów przeszedł pewną ewolucję. Wiąże się ona nie tylko z czasem, ale i określonym ocenianiem, opiniowaniem mediów przez władzę papieską. Początkowy nakaz głoszenia zbawienia został tym samym wzbogacony najpierw o prawo używania środków społecznego przekazu, a następnie o prawo do ich posiadania. W Inter mirifica ${ }^{22}$ czytamy: „Kościołowi przysługuje [...] naturalne prawo używania i posiadania wszelkiego rodzaju owych środków, o ile są one konieczne lub pomocne w chrześcijańskiej działalności wychowawczej i w każdej jego pracy podejmowanej dla zbawienia dusz" (DSP, nr 3). Środki te nie mogą jednak naruszać porządku moralnego. W poszczególnych Kościołach lokalnych troska o odpowiedzialne wykorzystanie środków społecznego przekazu powierzona została Konferencjom Episkopatu, a następnie ordynariuszom miejsca. Czytamy:

jak Apostołowie używali środków przekazu będących wówczas do ich dyspozycji - tak samo za naszych dni powinno się korzystać z pomocy nowoczesnej techniki w pracy apostolskiej. Nikt więc nie może uważać, że wiernie wypełnia nakaz Chrystusa, jeżeli przechodzi obojętnie obok ułatwień, jakich dostarczają omawiane środki w niesieniu nauki ewangelicznej do jak największej liczby ludzi (CP, nr 126).

\section{Ewangelizacja za pośrednictwem środków masowego przekazu}

W roku 1974 miał miejsce Synod Biskupów poświęcony ewangelizacji. Zastanawiano się wówczas między innymi nad tym, czy dotychczasowe metody ewangelizacji są skuteczne, czy należy je zaktualizować. Wynikiem pracy Synodu była adhortacja apostolska o ewangelizacji w świecie współczesnym Evangelii nuntiandi.

${ }^{18}$ Dzień ten w Kościele powszechnym obchodzony był od 1967 roku, a w Kościele polskim od 1975 roku.

${ }^{19}$ Komisje tę powołał do życia Paweł VI w 1964 roku.

${ }^{20}$ S. Pamuła, dz. cyt., s. 23-24.

${ }^{21}$ Tamże, s. 24.

${ }^{22}$ Szersze informacje na temat tego dokumentu odnaleźć można w: A. M. Deskur, Papieska Komisja do spraw Społecznego Przekazu i Realizacji Soborowego Dekretu Inter mirifica, ,, W nurcie zagadnień soborowych", Warszawa 1972, s. 345-361. 
W adhortacji podkreślano, że sposób ewangelizowania powinien być dostosowany do poziomu intelektualnego człowieka, jak również do warunków jego życia. Dlatego ciaggła aktualizacja metod ewangelizacji stanowi ważny obowiązek wszystkich duchownych. W ten sposób Kościół otworzył się w pełni na możliwości mass mediów, nie kopiując jednak świeckich sposobów wykorzystania ich, ale przekształcając je dla swoich potrzeb oraz stosując dużą kontrolę, tak, by uniknąć deformacji treści przekazu. Orędzie ewangeliczne powinno bowiem dotrzeć do ludzi bez najmniejszych zmian.

Sobór Watykański II zalecił obchodzenie w ciagu roku jednego dnia poświęconego zagadnieniu środków społecznego przekazu. Od roku 1966 dzień ten został nazwany Światowym Dniem Środków Społecznego Przekazu ${ }^{23}$ i obchodzono go każdorazowo w niedzielę po Wniebowstapieniu i przed Zesłaniem Ducha Świętego. Dni te poświęcone były różnym problemom z zakresu mass mediów. Porównując jednak treść poszczególnych dni można zauważyć, że generalnie skupiają się one wokół problemu pokoju na świecie i roli, jaką mogą spełnić mass media w tej dziedzinie, jak również na ich wpływie na rodzinę, a zwłaszcza na młodzież ${ }^{24}$. Wspólną cechą orędzi jest także generalnie pozytywny stosunek do komunikacji społecznej i środków społecznego przekazu.

Przejdźmy teraz do innych dokumentów okresu posoborowego, poruszających problematykę mass mediów i realizacji ewangelizacji za ich pośrednictwem.

Jednym z nich jest Kodeks Prawa Kanonicznego z 1983 roku, który zastąpił kodeks z roku 1917. W nowym kodeksie środki masowego przekazu zostały ukazane jako trwały element życia społecznego i jako narzędzie Kościoła. Poświęconych im zostało kilka kanonów, między innymi kanon 666, mówiący o konieczności posiadania odpowiedniej wiedzy na temat środków społecznego przekazu, o wstrzemięźliwości w korzystaniu z nich i o unikaniu treści, mogących zaszkodzić osobom duchownym. W kanonie 747 stwierdzono z kolei, że Kościół „ma obowiązek i wrodzone prawo przepowiadania Ewangelii wszystkim narodom, niezależnie od jakiejkolwiek ludzkiej władzy, także z zastosowaniem właściwych sobie środków społecznego przekazu". Do wykorzystania tych środków w ewangelizacji świata zachęca również kanon 761 i 779, a kanon 804 zwraca uwagę na możliwość nauczania i wychowania katolickiego zarówno w szkołach, jak też poprzez środki społecznego przekazu, podlegające władzom kościelnym. Z kolei kanon 823 reguluje przepisy, dotyczące autorów tekstów religijnych.

Kodeks Prawa Kanonicznego stanowi dokument najwyższej rangi, wprowadzający mass media do metod, którymi posługuje się Kościół między innymi w dziele ewangelizacji świata ${ }^{25}$.

\footnotetext{
${ }^{23}$ Pierwszy Światowy Dzień Środków Społecznego Przekazu odbył się 7 maja 1967 roku.

${ }^{24}$ Szczegółowe teksty przemówień odnaleźć można w: M. Lis (red.), Orędzia papieskie na Światowe Dni Komunikacji Społecznej 1967-2002, Częstochowa 2002.

${ }^{25}$ Por. tamże, s. 117-119.
} 
Oprócz Kodeksu Prawa Kanonicznego istotnymi dokumentami posoborowymi, poruszającymi problem środków społecznego przekazu, są: Ratio fundamentalis institutionis sacerdotalis opracowany przez Kongregację Wychowania Katolickiego w 1970 roku, dotyczący wprowadzania tematyki społecznej komunikacji i środków społecznego przekazu do programów kształcenia przyszłych kapłanów, i opracowane przez tę samą Kongregację w roku 1986 Wskazówki odnośnie do formacji przyszłych kapłanów w zakresie środków społecznego komunikowania ${ }^{26}$.

W czasie swego pontyfikatu Jan Paweł II wiele miejsca poświęcił problematyce mediów, prezentując ją głównie w orędziach przygotowanych na Światowy Dzień Środków Społecznego Przekazu, w listach okolicznościowych, przemówieniach, audiencjach i podczas spotkań z dziennikarzami. Papież zwracał uwagę między innymi na prawo do informacji, podkreślając, że zapewnienie pełnej i obiektywnej informacji stanowi niezbędny warunek tego, by mass media przyczyniały się do dobra i szybkiego postępu społeczeństwa ${ }^{27}$. Uwypuklał on również problem „wewnętrznej wolności”, przysługującej środkom społecznego przekazu, podkreślając, że brak tej wolności może spowodować manipulację treścią przekazu, życia społecznego i samego człowieka ${ }^{28}$. Papież zwracał uwagę również na negatywną stronę mediów, poruszając między innymi problem wprowadzania przez środki społecznego przekazu przejścia od rzekomej wolności do zupełnego braku ograniczeńn ${ }^{29}$. Taka sytuacja grozi niebezpieczeństwem całkowitego odrzucenia zobowiązań moralnych i psychicznym zniewoleniem człowieka, który utraci zdolność wartościowania ${ }^{30}$.

W swych wypowiedziach Jan Paweł II zwracał uwagę także na wpływ, jaki mają media na odbiorców. Oprócz przypisywania im elementów pozytywnych, dostrzegał w nich również niebezpieczeństwo propagowania konsumpcjonizm, tworzenia pozornych wartości, trwałe uzależnienie psychiczne, niszczenie intelektu i działanie na podświadomość. Wśród szczególnie zagrożonych negatywnym wpływem mediów wymienia Papież młodzież i najmłodszych członków rodziny.

Podobnie jak przy omawianiu innych problemów natury społecznej, tak samo w przypadku mass mediów, w centrum swego nauczania stawia Jan Paweł II człowieka i ochronę jego godności. Podkreśla on między innymi, że za nadawane przez środki społecznego przekazu treści, moralnie odpowiedzialny jest człowiek, który powinien traktować swą pracę poważnie. Podobnie odbiorca

${ }^{26}$ Szersze informacje na ten temat znajdują się w: J. Chrapek (red.), Kościót a środki społecznego przekazu, Warszawa 1990, s. 255-256.

${ }^{27}$ Por. Jan Paweł II, Prawa i obowiazki dziennikarza, Przemówienie do przedstawicieli prasy międzynarodowej, OsRomPol 7-8 (1982), s. 21.

${ }^{28}$ Por. Jan Paweł II, Kościót potrzebuje sztuki czy sztuka potrzebuje Kościoła?, OsRomPol 2 (1981), s. 18-19; Jan Paweł II, Informacja, świadectwo, prawda, OsRomPol 5-6 (1983), s. 5.

${ }^{29}$ Jan Paweł II, Komunikacja społeczna w stużbie sprawiedliwości i pokoju, Orędzie na Światowy Dzień Środków Społecznego Przekazu, OsRomPol 8 (1987), s. 6.

${ }^{30}$ Por. tamże. 
treści medialnych zobowiązany jest do odpowiedzialności i krytycznego odbioru prezentowanych treści ${ }^{31}$. Na tym tle pojawia się problem treści umieszczonych w coraz szybciej rozwijającym się środku komunikacji masowej, jakim jest Internet. Kościół nie pozostaje bierny wobec tego osiągnięcia techniki i stara się wykorzystać je w swej działalności duszpasterskiej.

\section{Kościół w świecie Internetu. Internet w życiu Kościoła}

Internet stanowi nawet jedno z mediów, które Sobór Watykański II określił jako „wspaniały wynalazek techniczny” (DSP, nr 1). Pozytywne stanowisko wobec Internetu wynika z faktu, że może on zostać wykorzystany do sprostania ludzkim potrzebom ${ }^{32}$. W innym dokumencie ten sam Sobór zauważa, że „choć należy starannie odróżnić postęp ziemski od wzrostu Królestwa Chrystusowego, to przecież dla Królestwa Bożego nie jest obojętne, jak dalece postęp ten może przyczynić się do lepszego urządzenia społeczności ludzkiej” (KDK, nr 39). Dziś można powiedzieć, że myśl soborowa w sposób szczególny odnosi się do Internetu, który wpływa nie tylko na sposób komunikowania się, ale także na sposób postrzegania życia, w którym „kościelna praktyka przekazu powinna być przykładna, odbijając w sobie najwyższe standardy prawdziwości, rzetelności, wrażliwości na prawa ludzkie i inne stosowne zasady i normy" (EwS, nr 26). W Communio et Progressio jasno wykazano przecież, że media stały się nowym sposobem przedstawienia ludziom przesłania Ewangelii (por. CeP, nr 128). Papież Paweł VI zauważył nawet, że Kościół „czułby się winny przed Panem”, gdyby nie wykorzystał ich w dziele ewangelizacji świata (por. EN, nr 45), a Jan Paweł II określił je jako „pierwszy aeropag współczesnych czasów” i zaznaczył, że nie można ograniczyć się jedynie do używania ich przy szerzeniu orędzia chrześcijańskiego, ale należy włączyć samo orędzie w nową kulturę przez nie wykreowaną (por. RMis, nr 37).

Wszystkie powyższe wskazania w sposób szczególny odnieść można do Internetu, który stworzył przecież całkiem nowe i wyjątkowe możliwości do głoszenia Dobrej Nowiny, do dotarcia z nią do szerokiego kręgu odbiorców; możliwości, które nie istniały nigdy wcześniej w historii Kościoła ${ }^{33}$. Aby jednak móc w pełni korzystać z szansy, jaką daje Internet, Kościół powinien dobrze go zrozumieć, poznać kierujące nim zasady, jego twórców i użytkowników. Takie poznanie jest niezbędne do skutecznego dialogu z ludźmi, głównie młodymi, przesiąkniętymi nowoczesną technologią. Gdy Kościół pozna Internet, będzie

${ }^{31}$ Por. K. Pokorna-Ignatowicz, dz. cyt., s. 136.

${ }^{32}$ Stanowisko to można zauważyć na przykład w takich dokumentach, jak: Inter mirifica; Communio et Progressio; Aetatis Novae, Etyka reklamy, Etyka w środkach społecznego przekazu.

${ }^{33}$ Por. Jan Paweł II, Rozgłaszajcie na dachach. Ewangelia w epoce globalnej komunikacji, Orędzie na Światowy Dzień Środków Społecznego Przekazu, OsRomPol 22 (2001), s. 4. 
mógł w pełni korzystać z jego zalet, widzianych z religijnego punktu widzenia, a zalet tych Internet posiada wiele. Jest on ,źródłem wiadomości i informacji o wydarzeniach, ideach i osobistościach z życia religijnego oraz służy jako narzędzie ewangelizacji i katechezy [...] dostarcza informacji, niesie otuchę, stwarza sposobność do modlitwy ludziom zmuszonym do pozostawania w domach lub w instytucjach publicznych" (EwS, nr 11). Poza tym Internet daje możliwość bezpośredniego dostępu do ważnych zasobów religijnych i duchowych ${ }^{34}$, stwarza możliwość przezwyciężenia bariery odległości i izolacji, umożliwiając kontakt z innymi ludźmi na całym świecie, łącząc ich w ten sposób w swoistego rodzaju wirtualne społeczności wiary. Znajduje on również zastosowanie w rozlicznych formach działalności i programach kościelnych, w tym w misji nowej ewangelizacji i tradycyjnej misji ad gentes, w katechezie, w przekazie wiadomości $\mathrm{i}$ informacji, w apologetyce, zarządzaniu i administracji, i w pewnych formach duszpasterskiego poradnictwa. I chociaż wirtualna przestrzeń wykreowana przez Internet nie może zastapić rzeczywistej wspólnoty, sakramentów, liturgii i bezpośredniej proklamacji Ewangelii, to z całą pewnością może je uzupełniać, wzbogacając tym samym życie religijne. Może również wspomagać duszpasterzy w pracy z tymi członkami Kościoła, w stosunku do których mają oni utrudniony dostęp, na przykład w pracy z osobami mieszkającymi na odległych terenach, czy z członkami innych grup religijnych.

Poza tym Internet daje możliwość zatarcia rozróżnienia na tych, którzy coś komunikują i na tych, którzy odbierają komunikowane treści (por. CeP, nr 15), stwarza bowiem sytuację, w której każdy może stać się jednocześnie nadawcą i odbiorcą. O takiej możliwości wspominał już Sobór Watykański II w Konstytucji Dogmatycznej o Kościele Lumen Gentium, w której czytamy, że wszyscy członkowie Kościoła powinni przedstawiać duszpasterzom „swoje potrzeby i życzenia z taką swobodąi ufnościa, jaka przystoi synom Bożym i braciom w Chrystusie [...] mają możność, a niekiedy nawet obowiązek ujawniania swojego zdania w sprawach, które dotyczą dobra Kościoła” (KK, nr 37). I chociaż prawdy wiary nie ulegają zmianie i nie ma w nich miejsca na dowolną interpretację, to pozostawiają ogromny obszar, w którym osoby należące do Kościoła mogą prezentować swoje poglądy (por. CeP, nr 117). Dzięki stworzeniu możliwości wzajemnej komunikacji i wymiany informacji ,w obie strony” Internet dokonał rewolucyjnej zmiany wcześniejszej ery prasowo-radiowo-telewizyjnej, w której jedynie garstka wybranych decydowała o tym, co będą odbierały i myślały tłumy, na erę, w której wielu mówi za pośrednictwem Sieci do szerokiego grona odbiorców, samemu również stając się odbiorcą ${ }^{35}$. Podobna opinia wyrażona została w Kodeksie Prawa Kano-

${ }^{34}$ Na przykład: bibliotek, muzeów, miejsc kultu, dokumentów Nauczycielskiego Urzędu Kościoła, pism Ojców i Doktorów Kościoła.

${ }^{35}$ Por. T Zasępa, Komunikacja cybernetyczna wyzwaniem dla Kościoła, w: T. Zasępa, R. Chmura (red.), Internet i nowe technologie ku społeczeństwu przyszłości, Częstochowa 2003, s. 52. 
nicznego (por. KPK nr-y 212.2, 212.3) i dwóch dokumentach Papieskiej Rady ds. Środków Społecznego Przekazu - Aetatis novae i Etyka w Środkach Społecznego Przekazu. Pierwszy z nich określa ową dwukierunkową komunikację i opinię publiczną jako ,jeden ze sposobów konkretnej realizacji charakteru Kościoła jako communio" (AN, nr 10). Drugi natomiast zauważa, że „dwustronny przepływ informacji i poglądów między duszpasterzami i wiernymi, wolność wypowiadania się podporządkowana dobru wspólnoty i respektująca rolę Magisterium w ochronie tegoż dobra, wreszcie odpowiedzialna opinia publiczna - wszystko to jest ważnym przejawem «podstawowego prawa do dialogu i informacji w ramach Kościoła»" (Etyka w Środkach Społecznego Przekazu, nr 26).

Kolejnym obszarem, w którym Kościół stara się wykorzystać Internet, jest edukacja. Niezbędne staje się na tym polu kształcenie medialne, które powinno stać się częścią całościowego programu edukacyjnego, dostępnego dla członków Kościoła. Kształcić należy zwłaszcza ludzi młodych, którzy, jak zauważa Communio et Progressio, staną się przez to nie tylko odbiorcami, ale i twórcami epoki społecznego przekazu, która właśnie nastała (por. CeP, nr 107).

Obok szans, jakie stwarza Kościołowi Internet, pojawiają się również konkretne problemy, z których Magisterium w pełni zdaje sobie sprawę i przed którymi przestrzega ${ }^{36}$. W niektórych bowiem przypadkach treści prezentowane w Internecie mogą wydawać się obojętne lub wręcz wrogo nastawione w stosunku do Kościoła $^{37}$. Wynika to w dużym stopniu z przepojenia kultury medialnej typowo postmodernistyczną mentalnością ${ }^{38}$. Niektóre strony prezentowane w Internecie mogą wręcz przynieść zjawisko ekstrapolacji w stosunku do religii i zachęcać do przyjęcia konsumenckiego podejścia do wiary ${ }^{39}$.

Innym zagrożeniem, $\mathrm{z}$ powodu którego Kościół pozostaje $\mathrm{w}$ dystansie do Internetu, jest tworzenie rzeczywistości, w której zaciera się prawda między tym, co rzeczywiste, a tym, co wykreowane. Należy bowiem pamiętać, o czym wspomniano już wcześniej, że Internet nigdy nie stanie się zamiennikiem realnej obecności Chrystusa w Eucharystii, nie zastapi sakramentalnej rzeczywistości żadnego z pozostałych sakramentów i nie da możliwości współudziału w kulcie sprawowanym w żywej wspólnocie.

Jednak mimo zagrożeń ze strony Internetu, Kościół wciąż pozostaje na niego otwarty, zachęcając swych członków do korzystania z jego możliwości w wypełnianiu misji powierzonej mu przez Chrystusa. Odsuwanie się od nowoczesnej technologii uważa Kościół za wręcz niemożliwe do zaakceptowania, powoduje ono bowiem ograniczanie możliwości poznania Chrystusa przez tych wszyst-

\footnotetext{
${ }^{36}$ Szerokie informacje na ten temat zawarte zostały w dokumencie Etyka $w$ Internecie.

${ }^{37}$ Można wspomnieć tu na przykład o witrynach internetowych przesiąkniętych nienawiścią, poświęconych znieważaniu lub atakowaniu określonych grup religijnych, zawierających treści pornograficzne, zachęcających do wstępowania do sekt, proponujących okultyzm czy praktyki satanistyczne.

${ }^{38}$ Por. Jan Paweł II, Rozgłaszajcie..., s. 5.

${ }^{39}$ Tamże.
} 
kich, do których wiadomość o Nim jeszcze nie dotarła ${ }^{40}$. Jan Paweł II zauważa nawet, że

metody ułatwiania komunikacji i dialogu pośród członków Kościoła mogą umocnić więzi jedności między nimi. Natychmiastowy dostęp do informacji umożliwia pogłębienie dialogu ze współczesnym światem [...] Kościół może prędzej informować [...] o swych przekonaniach i wyjaśniać powody postaw w konkretnej kwestii czy konkretnej sytuacji.

Szczególne wyzwanie dla Kościoła stanowi wspólnota wirtualna i jej zdolność samoorganizowania się. Wspólnota taka może reklamować w Internecie formę kultu religijnego ${ }^{41}$. Nie może ona jednak być pozostawiona samej sobie, ale powinna być przez Kościół wychowywana ${ }^{42}$. Inną formę obecności Kościoła w Internecie stanowi obecność porządkująca i wypracowanie reguł bycia on-line ${ }^{43}$.

Wszystko to wskazuje na fakt, iż Kościół nie odgradza się od Internetu, ale stara się z niego korzystać. Nie koncentruje się wyłącznie na biernym jego odbieraniu, ale raczej stara się zachęcać swych członków do owocnego korzystania z Sieci i używania jej w dziele ewangelizacji świata ${ }^{44}$.

Potwierdzeniem tego może stać się chociażby fakt wczesnego uruchomienia przez Stolicę Apostolską serwisu www.vatican.va, będącego oficjalną witryną Watykanu ${ }^{45}$. Poza tym Papież prezentował stanowisko Kościoła na temat Internetu w licznych publicznych wypowiedziach. Zresztą na temat Internetu wypowiadał się nie tylko Jan Paweł II. Problemem tym zajął się również między innymi episkopat niemiecki, którego Komisja do Spraw Mediów opracowała raport Multimedia - przeobrażenia ku społeczeństwu informacji ${ }^{46}$, poświęcony rozwojowi mediów i ich wpływu na różne dziedziny życia. W Polsce obradujący w latach 1991-1999 II Polski Synod Plenarny poruszył problem Internetu w czterech punktach swych obrad. Wymienia go między innymi narzędziami ewangelizacji ${ }^{47}$, wspominając dwie najbardziej popularne katolickie inicjatywy w In-

${ }^{40} \mathrm{Na}$ temat wykorzystania Internetu przez chrześcijan pisze: M. Robak, Zarzućcie sieć. Chrześcijanie wobec wyzwań Internetu, Warszawa 2001.

${ }^{41}$ Jako przykład mogą posłużyć rekolekcje wielkopostne organizowane w Internecie. Informacje na ten temat odnaleźć można m.in. w: D. Kowalczyk, Poszukujac Boga w komputerze. Internetowe rekolekcje wielkopostne, Kraków 1998.

${ }^{42}$ Por. T. Zasępa, Komunikacja cybernetyczna..., s. 52-53.

${ }^{43}$ Por. tamże, s. 53.

${ }^{44}$ Por. M. Robak, Czy Kościół lubi Internet? Sieć komputerowa w świetle wypowiedzi Kościoła katolickiego, w: T. Zasępa, R. Chmura (red.), dz. cyt., s. 55.

${ }^{45}$ Szerzej na temat strony watykańskiej i innych stron katolickich w Internecie pisze: C. Fox, Katolicyzm w Internecie, Warszawa 1997.

${ }^{46}$ Multimedia. Der Wandel zur Informationsgesellschaft. Tłumaczenie dokumentu na język polski opublikowane zostało w specjalnym wydaniu Przeglądu Powszechnego 3 (1996), s. 28-49.

${ }^{47}$ Por. II Polski Synod Plenarny, Potrzeba i zadania nowej ewangelizacji na przełomie II i III tysiqclecia chrześcijaństwa, nr 36, w: II Polski Synod Plenarny (1991-1999), Warszawa-Poznań 2001. 
ternecie ${ }^{48}$, jako przykład wykorzystania możliwości Internetu przez Kościół ${ }^{49}$, zachęcając wiernych do posługiwania się siecią elektroniczną i przypominając o obowiązku utrzymania lokalnych mediów katolickich ${ }^{50}$ i podając konkretne wskazania co do wykorzystania omawianego medium ${ }^{51}$.

W roku 1999 Papieska Rada do Spraw Środków Społecznego Przekazu wydała wspominany już wcześniej dokument Etyka w środkach społecznego przekazu, w którym odniosła się między innymi do zjawiska Internetu. W 24 numerze omawianego dokumentu czytamy: „,w sposób szczególny niepokój budzi Internet z powodu radykalnie nowych skutków, które przynosi: jak utrata istotnej wiarygodności narzędzi informacji, niezróżnicowana uniformizacja przekazów, które zostają w ten sposób sprowadzone do czystej informacji, brak odpowiedzialnej reakcji i pewne osłabienie kontaktów międzyosobowych". Dalej zwrócono uwagę na dążność ludzi do stworzenia sieci natychmiastowego przekazu informacji i konieczność badania skutków wykorzystania nowych technologii, zwłaszcza przez etykę (por. EwS 27). Obok więc entuzjazmu, który prezentował Kościół w stosunku do Internetu, pojawiła się także konstruktywna krytyka i ostrożność.

Śledząc kolejne wypowiedzi Kościoła na temat omawianego środka masowego przekazu nie można pominąć orędzia Jana Pawła II przygotowanego na XXXV Światowy Dzień Środków Społecznego Przekazu pod tytułem Rozgłaszajcie na dachach. Ewangelia $w$ dobie globalnej komunikacji. Papież pisał w nim o konieczności angażowania się Kościoła w zmieniający się świat komunikacji społecznej i zwracał uwagę na fakt, iż mimo możliwości zatarcia różnicy między prawdą i fikcją, media dają możliwość rozpowszechnienia prawdy wśród licznego grona odbiorców ${ }^{52}$. Poza tym Ojciec Święty wielokrotnie wzywał do głoszenia Ewangelii za pomocą środków społecznego przekazu i wymieniał możliwości, jakie stwarza Internet w rozpowszechnianiu informacji religijnych i nauczania Kościoła ${ }^{53}$. Właściwie orędzie to było pierwszym dokumentem papieskim tej rangi mówiącym wprost o Internecie ${ }^{54}$.

Krótko po ogłoszeniu omawianego orędzia Papieska Rada do Spraw Środków Społecznego Przekazu zapowiedziała przygotowanie kolejnych dokumentów poświęconych Internetowi. Przewodniczący Rady - John Foley - ogłosił w swym przesłaniu na Światowe Dni Komunikacji w Wiedniu, że będą one do-

${ }^{48}$ www.mateusz.pl, www.opoka.pl

${ }^{49}$ Por. II Polski Synod Plenarny, Ewangelizacja kultury i środków społecznego przekazu, nr 49, w: II Polski Synod Plenarny..., s. 104, 113-114.

${ }^{50}$ Por. tamże, $\mathrm{nr} 85$.

${ }^{51} \mathrm{~W}$ nr 90 dokumentu czytamy: „Internet stanowi ogromną pomoc w docieraniu do różnego rodzaju informacji. Dlatego, chociaż słusznie Kościół krytykuje «zaśmiecanie» Internetu, winno się także dostrzegać wielkie możliwości tego medium i wykorzystywać je w celu szerzenia Dobrej Nowiny. Należy zatem dbać m.in. o zakładanie i odnawianie katolickich stron WWW".

${ }_{52}$ Por. Jan Paweł II, Rozgłaszajcie..., s. 2.

${ }_{53}$ Por. tamże, s. 3.

${ }^{54}$ Por. M. Robak, Czy Kościót lubi Internet?..., s. 63. 
tyczyły etyki w Internecie i możliwości efektywnego wykorzystania go w działalności ewangelizacyjnej Kościoła. Przemówienie Foleya było najobszerniejszą z dotychczasowych wypowiedzi hierarchii kościelnej na temat Sieci. Poświęcone zostało w całości komputeryzacji i Internetowi. Foley twierdził w nim, że

Jezus dał swojemu Kościołowi mandat nauczania wszystkich narodów. Internet oferuje Kościołowi możliwość, by zachowane przesłanie Jezusa Chrystusa uczynić dostępnym dla każdego na świecie, kto ma dostęp do Internetu. W społeczeństwach, które nie zgadzają się na obecność księży, sióstr, braci lub świeckich misjonarzy, Internet może przynieść tym zaangażowanym w duchowe poszukiwanie lub też tym, którzy są po prostu ciekawi, okazję informacji i inspiracji, do których w inny sposób nie było dostępu ${ }^{55}$.

Arcybiskup zwrócił również uwagę na możliwości, które otwierają się przed Internetem, wymieniając wśród nich możliwość dialogu i odpowiadania na pytania, interaktywne szkolenia i kierownictwo duchowe, zdecydowanie odrzucając jednak możliwość spowiedzi on-line $e^{56}$ i ukazując pewne problemy, jakie wiążą się z pełną akceptacją tego medium ${ }^{57}$, wskazując wśród nich zagrożenie prywatności jednostki, łamanie praw autorskich, pornografię i uzależnienie od Interne$\mathrm{tu}^{58}$. Dokonując podsumowania wypowiedzi, Foley zauważył jednak, że Internet stwarza więcej możliwości do czynienia dobra niż zła i jedynie od człowieka zależy jak go wykorzysta.

\section{Zakończenie}

Jak wynika z przytoczonych wypowiedzi Kościoła, pokłada on wielkie nadzieje w środkach społecznego przekazu i podchodzi do nich jak do narzędzia, którego wartość moralna zależy od sposobu, w jaki zostanie użyty przez człowieka.

Obok zwrócenia uwagi na niebezpieczeństwa, kryjące się za akceptacją środków masowej komunikacji, Magisterium zwraca uwagę również na jaśniejsze ich

${ }^{55}$ J. Foley, Internet Gives New Meaning to „Deus ex Machina”, Address for Communications Day, thumaczenie za: M. Robak, Czy Kościót lubi Internet?..., s. 63.

${ }^{56}$ Szczegółowe informacje na temat spowiedzi za pośrednictwem Internetu odnaleźć można w: M. Dziewiecki, Spowiedź przez Internet? Próba odpowiedzi na pytanie o możliwość spowiedzi na odległość, Apostoł Zbawiciela. Biuletyn Salwatoriańskiego Ośrodka Powołan 1 (2001), s. 21-22; A. Reuter, Krytyka komputerowej spowiedzi, Komputery i Biuro nr 34, dodatek do Gazety Katowickiej (wydanie katowickie) nr 193, z dnia 20.08.1996, s. 9.

${ }^{57}$ Patrz np. M. Robak, Moralność Internetu?, Więź 10 (1999), s. 21-32; S. Budzik, Internet i rzeczywistość wirtualna. Szanse i zagrożenia dla przekazu wiary u progu III tysiaclecia, Currenda 1 (2000), s. 140-153; J. Kloch, Sacrum i profanum w Internecie, Computerworld 33 (1997), s. $55-59$.

${ }^{58}$ Por. M. Robak, Czy Kościót lubi Internet?..., s. 63. 
strony i możliwości wykorzystania w działalności Kościoła, wzywając wiernych do korzystania z nich w sposób aktywny. I choć trudno przewidzieć z całą pewnością, w którą stronę rozwinie się dalsze nauczanie Kościoła na temat mediów, to można zauważyć, że obecnie zostały one przyjęte jako narzędzie działalności duszpasterskiej Kościoła, a zagrożenia, które ze sobą niosą, postrzegane były jako problemy do rozwiązania, a nie jako przyczyny rezygnacji z ich wykorzystania. W ten sposób wzywa Kościół do wychowania do odpowiedzialnego korzystania z mediów. Poza tym w swych wypowiedziach na temat Internetu i innych środków społecznego przekazu Magisterium popierało procesy, ułatwiające jednoczenie się ludzi, dialog, znoszenie nienawiści i uprzedzeń, popierając w ten sposób rozwój mass mediów.

Podsumowując rozważania na temat uczestnictwa Kościoła w świecie mediów i realizacji za ich pośrednictwem dzieła ewangelizacji świata, można zauważyć z całą pewnością, że zachowując pewien ,zdrowy” dystans, Kościół stara się wykorzystać je w swej działalności duszpasterskiej tam, gdzie tylko jest to możliwe, przestrzegając jednocześnie wszystkich ludzi dobrej woli przed niebezpieczeństwami, jakie mogą one za sobą pociagać ${ }^{59}$.

\section{Kirche in Medienwelt. Evangeliesierung in die Zeit der Computern (Zusammenfassung)}

XXI Jahrhundert zeigt uns eine gewaltige Entwicklung der Massenmedien und ihren Einfluss auf die Unwelt und das Leben eines Menschen. In einer so ausgebildeten Welt soll die Kirche diesen Einfluss der Massenmedien ausnutzen, um Ihr Evangelisationswerk zu fuhren.

Vorliegender Artikel gibt uns eine kurze Reflexion zum Thema der Teilnahme der Kirche an die Welt der Massenmedien und der Teilnahme der Massenmedien an den Kirchendienst.

${ }^{59}$ Por. tamże, s. 66. 